\title{
FAN1 Gene
}

National Cancer Institute

\section{Source}

National Cancer Institute. FAN1 Gene. NCI Thesaurus. Code C92478.

This gene is involved in the regulation of DNA repair. 